\title{
Robert Nęcek
}

\author{
Head of the Department of Media Education, University of John Paul II
}

\section{Understanding John Paul II's communication with the contemporary world on the example of Joanna Sobczyk-Pajak's painting}

\author{
Rozumienie komunikacji Jana Pawła II \\ ze światem współczesnym na przykładzie \\ malarstwa Joanny Sobczyk-Pająk
}

\begin{abstract}
The process of interpersonal communication as understood by John Paul II is a reality based on establishing mutual relations and cooperation. Communication requires a specific medium, and in this context the image becomes the communication medium, because the communication of John Paul II is presented on the plane of the image. That is why the papal painting made by Joanna Sobczyk-Pajak is a communication of beauty. John Paul II in a painting, fascinates at every step and in the way in which he amazed the world during his lifetime.

Of course, art is such a dimension of human

life that it can pose questions or answer them.

Everything depends on the imagination of the artist and the recipient himself. It seems, however,

that the painting by the Cracow artist from Podłęże is a call for basic values that make human life beautiful and meaningful. There is no pressure in this painting. Talking to the audience through the painting and serving them manifestations of papal communication, he asks people living today

about the values in their lives, about the sense of beauty, about the liberation of harmony in the heart. In this way, the essence of communication becomes the meeting with people.
\end{abstract}

KEYWORDS: communication, culture, empathy, beauty, painting as a form of communication, message, media, creating relations

\section{ABSTRAKT}

Proces komunikacji międzyludzkiej w rozumieniu Jana Pawła II jest rzeczywistością polegającą na nawiązaniu wzajemnych relacji i współdziałania. Komunikacja wymaga określonego medium, a w tym kontekście medium komunikacyjnym staje się obraz, gdyż na płaszczyźnie obrazu przedstawiona jest komunikacja Jana Pawła II. Dlatego malarstwo papieskie Joanny Sobczyk-Pająk jest komunikacją piękna. Ukazany obrazem Jan Paweł II fascynuje na każdym kroku, fascynuje w taki sposób, w jaki zadziwiał świat za życia. Oczywiście sztuka jest takim wymiarem ludzkiego życia, że może stawiać pytania lub na nie odpowiadać. Wszystko zależy od wyobraźni artystki i samego odbiorcy. Wydaje się jednak, że malarstwo krakowskiej artystki rodem z Podłęża jest wołaniem o podstawowe wartości, które czynią ludzkie życie pięknym i sensownym. W tym malarstwie nie ma żadnej presji. Rozmawiając z odbiorcami poprzez obraz i serwując im przejawy komunikacji papieskiej stawia pytania ludziom współcześnie żyjącym o wartości w ich życiu, o poczucie piękna, o wyzwolenie harmonii w sercu. Tym sposobem istotą komunikacji staje się spotkanie z ludźmi.

\section{SŁOWA KLUCZOWE:}

komunikacja, kultura, empatia, piękno, malarstwo komunikacją, przekaz, media, tworzenie więzi 


\section{INTRODUCTION}

The culture of closeness is the key to establishing interpersonal relations. Although the very phrase "culture of closeness" was created by Pope Francis, the teaching of John Paul II was also characterized in a very visible way. Closeness in word and posture has an extremely rich species load. Above all, it is about the bond of closeness, which is expressed in ordinary everyday communication. By means of communication understood in this way, the awareness of being accepted, understood and loved is liberated in our neighbour ${ }^{1}$. Then - even in pain - joy is born, and this joy is awakened from the "selfless meeting! Someone says: "You are important to me, I love you, I rely on you "' 2 . So what does communication mean? Well, communication "means creating relations between people", in which the tenderness of love manifests itself on every level.

In the context of John Paul II's communication with the world, the painting of the Krakow artist, straight from Podłęże by Joanna Sobczyk-Pająk, appears as one of her forms constituting an artistic expression of a beautiful path that evokes deep emotions and fills with joy ${ }^{4}$. Painting as "art is the fruit of the creative abilities of a human being who, in the face of visible reality, asks questions, tries to discover its deep sense and pass it on in a different language of forms, colours and sounds. Art can express and make visible the human need to explore the invisible, to express the desire and the search for infinity"5.

Being aware of this, it is worth presenting the papal concept of communication, the papal painting of Joanna Sobczyk-Pajak and the manifestations of understanding of papal communication in her art.

${ }^{1}$ Por. R. Nęcek, Od kapłaństwa do społeczeństwa. Wybrane kwestie z nauki społecznej papieża Franciszka, Kraków 2014, s. 84.

${ }^{2}$ Franciszek, Wiarygodni i konsekwentni. Spotkanie z seminarzystami, nowicjuszami i nowicjuszkami (6.07.2013), „L`Osservatore Romano” nr 8-9 (2013), s. 42.

${ }^{3}$ Franciszek, Prawdziwa władza jest służbq, Kraków 2013, s. 400.

${ }^{4}$ Por. Benedykt XVI, Sztuka i kultura umacniaja naszq więź z Panem (Castel Gandolfo, 30.08.2011), „L`Osservatore Romano” nr 10-11 (2011), s. 45.

${ }^{5}$ Tamże, s. 46. 


\section{THE PAPAL CONCEPT OF INTERPERSONAL COMMUNICATION}

The process of interpersonal communication as understood by John Paul II is a reality taking place within a given community and consists in establishing mutual relations and cooperation. The term "to communicate" means "to make something common, to give something to the public, to transfer message, to notify about something" ${ }^{\prime \prime}$. In this way, the essence of communication becomes the meeting with people. There is no social interaction without communication. On the other hand, communication requires a specific medium, i.e. an instrument for transferring information in space and time. It can be a speech or a lecture, a letter or a print, or it can be a satellite link or a painted picture ${ }^{7}$. In other words, communication is an establishment of connection between people through sensorially perceivable means ${ }^{8}$. In this context they will be presented - participation in the process of communication, the message as a way to community and formation to receive beauty.

\section{On the other hand, communication requires a specific medium, i.e. an instrument for transferring information in space and time.}

\section{Participation in the communication process}

Undoubtedly, interpersonal communication is not only a communication of information, but also a communication of a person who communicates a specific content. The more noteworthy the message becomes the content communicated by the artists, because the artists are able to make the image attractive,

${ }^{6}$ Por. Słownik Wyrazów Obcych PWN. Wydanie nowe I, Warszawa 1995, s. 578.

${ }^{7}$ Por. T. Goban-Klas, Komunikowanie i media, w: Dziennikarstwo i świat mediów, red. Z. Bauer, E. Chudziński, wyd. II zm., Kraków 2000, s. 12.

${ }^{8}$ Por. M. Golka, Bariery w komunikowaniu i społeczeństwo (dez) informacyjne, Warszawa 2008, s. 4. 
understandable and encouraging to think deeper through various ways of art ${ }^{9}$. In this way, participation in the creation of culture by art is not possible without communication. It should be emphasized that culture expressed through art becomes a specific way of human existence, which creates "a set of connections between persons living within each community, defining the interpersonal and social character of human existence. The subject and creator of culture is the man who finds his own expression and balance in it"10. This means that participation in communication and culture determines the level of humanity of the human being. The culture expressed in art itself is "communication - not only and not so much between man and the environment, over which man is called to rule, but also between man and man"11. It is not by chance that Pope Benedict XVI, the successor of Pope Wojtyla, noted that the desire to communicate is nothing more than "a modern expression of the basic and constant tendency of man to cross himself in order to establish relationships with other people. For when we open ourselves up to others, we satisfy our deepest needs and achieve the fullness of humanity"12. Such an approach to the matter allows us to understand the essence of communication as a message, creating culture, helping to understand the world, creating interaction with others and gathering social memory ${ }^{13}$. Therefore, communication through art is something very important, because it shapes the common good of the society, which combines participation and cooperation, which is the feature of person and society.

${ }^{9}$ Por. Jan Paweł II, Orędzie na XVI Światowy Dzień Środków Społecznego Przekazu - 1982. Środki społecznego przekazu a problemy ludzi starszych, w: Jan Paweł II, Dzieła zebrane, t. 4, Kraków 2007, s. 877.

${ }^{10}$ Jan Paweł II. Orędzie na XVIII Światowy Dzień Środków Społecznego Przekazu - 1984. Środki społecznego przekazu pomostem między wiarq i kultura, w: Jan Paweł II, Dzieła zebrane, t. 4, Kraków 2007, s. 882.

${ }^{11}$ Tamże, s. 883.

${ }^{12}$ Benedykt XVI, Nowe technologie, nowe relacje. Trzeba rozpowszechniać kulturę szacunku, dialogu i przyjaźni. Orędzie na 43 Światowy Dzień Środków Społecznego Przekazu, „L'Osservatore Romano" nr 3 (2009), s. 5.

${ }^{13}$ Por. M. Golka, Bariery w komunikowaniu i społeczeństwo (dez)informacyjne, Warszawa 2008, s. 4. 


\section{Message as a route to community}

The papal understanding of communication with the world is based on a vision of a message leading to community, and the artist is undoubtedly surrounded by a circle of people enchanted by his sensitivity to beauty. John Paul II, speaking about the community of people, points to selfless love as the basis. It is the love for art and the love for the artist that leads to the formation of a community of people who are united by beauty and its depth. The artist's love for beauty can release the process of feelings communication for the viewer, looking for the meaning and self-fulfilment. Although the way of communicating feelings can sometimes cause problems in interpersonal relations, the need to share them is something proper and worthy of desire.

\section{The artist's message is a specific process of communicating beauty by arousing deeper feelings.}

The artist's message is a specific process of communicating beauty by arousing deeper feelings. This means that his message leads to community and creates goodness when aesthetics is combined with ethics. Then the aim of an artist's work is always good, and his fascination with the work of art has no neutral value. To create culture through art is always to give personal testimony "when a concrete person shares his faith in the risen Lord with others - it has a significant meaning, just like other traditional forms of proclaiming the Word of God"14. In this way, the artist's gaze reaches much deeper than the average, and it is a free gaze, and this gaze is used by others. His imaging language of communication in all circumstances is based on duc in altum - go deep, and where there is depth, there is community.

${ }^{14}$ Por. Jan Paweł II, Orędzie na XXXIV Światowy Dzień Środków Społecznego Przekazu 2000, w: Jan Paweł II, Dzieła zebrane, t. 4, Kraków 2007, s. 933. 


\section{Formation for the reception of beauty}

John Paul II reminded us that "in a culture that feeds on passing phenomena, there is a danger that people will be inclined to attribute greater significance to facts than to values"15. Meanwhile, there is an urgent need to shape man's sensitivity to beauty. In "Letter to Artists" the Pope directly noted that the world needs artists, because in the vast panorama of culture they secure a sublime form of art, which is the formation to perceive beauty. The point is that sensitivity to beauty becomes a valuable service for the common good, because a sensitive viewer builds a sensitive society ${ }^{16}$. This means that "every authentic form of art is a peculiar way of accessing the deeper reality of a man and the world"17. It also means that the artist's ministry is associated with responsibility for the spiritual development of the recipient. For this reason, it is worth supporting the formation for the reception of beauty in various ways, because through beauty the life of each nation is renewed ${ }^{18}$. Additionally, the artist's ministry is usually undervalued financially, and in the era of the free market it becomes more and more difficult to obtain patronage. Archbishop Józef Życiński says it bluntly: "Our sensitivity to beauty does not usually bring us any benefits in the evolutionary struggle for existence. No one goes to the philharmonic to impress their neighbours or to have an opinion of a man of culture in the circle of their closest relatives. We go because we love the beauty of music, although there are no measurable benefits from this love"19. In this context, Karol Wojtyła was raised from an early age to a very personal reference to beauty. What is more, he interpreted the focus on beauty in the spirit of Norwidian love ${ }^{20}$. Therefore, the key to the sensitivity to beauty are the words of the bard: "What do you know about beauty?..." ... „the shape is Love"21. Being aware of this, Pope Wojtyła reminded us that through the paths of art one can "transfer

${ }^{15}$ Jan Paweł II, Orędzie na XXXVI Światowy Dzień Środków Społecznego Przekazu - 2002, w: Jan Paweł II, Dzieła zebrane, t. 4, Kraków 2007, s. 938.

${ }^{16}$ Por. Jan Paweł II, List do artystów, Watykan 1999, nr 3-4.

${ }^{17}$ Tamże, nr 6.

${ }^{18}$ Por. Jan Paweł II, List do artystów, Watykan 1999, nr 3-4.

${ }^{19}$ J. Życiński, Wartości w eterze, Lublin 1999, s. 23.

${ }^{20}$ Por. Z. S. Szpecht-Abramiuk, Piękno $w$ doświadczeniu egzystencjalnym Karola WojtyłyJana Pawła II, „Warszawskie Studia Teologiczne” nr 1 (2011), s. 29.

${ }^{21}$ C. K. Norwid, Promethidion: Bogumit, w: Pisma wybrane, t. 2, Poematy, Warszawa 1968, w. 109. 
human souls from the sensual world into eternal reality"22. It must be stated, therefore, that the experience of beauty is not only aestheticism, but above all the moment of experiencing love, when the beauty becomes a chance for love ${ }^{23}$.

\section{PAPAL PAINTING BY JOANNA SOBCZYK-PAJAK}

It should be noted that art can sometimes use a better message than other media, although to a large extent the artist's message is an individual one. From this perspective, one of the forms of communication is painting. The message proposed by the artists often becomes a different perception of the world, devoid of routine and sophistication. Therefore, in this context, it is worth looking at the painting of the Cracow artist, like Joanna Sobczyk-Pająk from Podłęże. Therefore, the following will be discussed: painting as a form of communication and selected painting poses of John Paul II in its approach.

\section{Painting as a form of communication}

Undoubtedly, painting is conducive to the establishment of interpersonal relations, and more precisely to the relations between the artist and the recipient of her work. Communication in art has always existed, because artists have always tried to convey the message of beauty through their paintings. Therefore, in case of Joanna Sobczyk-Pajak, the image becomes a form of communication with the world. By painting papal shots of John Paul II, the painter preserves the memory of the great pope, takes care of it and gives it to the audience to think about. Her work is expressed in oil painting and digital painting.

\section{Oil painting}

In one of her articles, the painter states that it is difficult to imagine communication today without a visual form"24. Painting is a perfect form of communication with the world, and at the same time the most traditional and well-known form of painting on canvas. It is also considered the most noble form. It is worth

${ }^{22}$ Jan Paweł II, List do artystów, Watykan 1999, nr 7.

${ }^{23}$ Por. Z. S. Szpecht-Abramiuk, Piękno $w$ doświadczeniu egzystencjalnym Karola WojtyłyJana Pawła II, „Warszawskie Studia Teologiczne” nr 1 (2011), s. 29.

${ }^{24}$ Por. J. Sobczyk-Pająk, Wizerunek współczesnego świętego $w$ malarstwie forma komunikacji ze światem, w: Św. Joanna Beretta Molla. Komunikacja i społeczne oddziaływanie, red. R. Nęcek, J. Sobczyk-Pająk, Kraków 2019, s. 89. 
noting that the time of painting oil paintings is an extended time, and everything depends on the size of the painting - for example, the painting of St. John Paul II placed in the side altar in the parish church of the Blessed Virgin Mary, Queen of Poland in Podłęże was painted for more than half a year.

You can use a brush to express yourself without words, because the painting speaks for itself. One of the painting techniques of Joanna Sobczyk-Pajak is oil painting. In her painting message, she tries to transfer emotions and feelings onto the canvas. It should be noted that a brush is a traditional painting tool, and oil paintings are painted with pigments bound by drying oil, which includes linseed oil, poppy seed oil or safflower oil. It is worth noting that oil painting allows retouching paintings by applying successive layers of paint to the painting.

The artist uses different oils in the same painting, depending on the expected effects. The oil itself can be boiled in pine resin in order to create a lacquer, valued for its gloss. The long drying time of oil paints allows the artist to change the colours or shapes painted on canvas. The paint dries through the oxidation process. The average period of drying is two weeks, although conservators claim that oil paintings in traditional technology become completely dry only in the period of 60-80 years.

Digital painting

The second painting form of Joanna Sobczyk-Pajak is digital painting. It is a new form of art. The artist uses painting techniques to create a digital image simply on a computer. It is a way of creating picture using computer tools. These include: Photoshop, a complex graphic program, a tablet with a stylus and other equally important programs. A sketch is made on paper, transferred to a tablet, on which the whole drawing is outlined in such a way that its contours are placed on the screen. Thanks to the digital program, the artist can create her own brush style. Thanks to digital painting, the painter from Podłęże combines two worlds: the world of art and the world of computer science. It is an attempt to fill the gap between traditional and digital painting. It is not by chance that John Paul II - taking into account the novelty of the message also in art - noted that "new forms of culture and art appear today. They become a powerful stimulus for believers to search for a more mature faith and to bear witness to it with a new faith"25.

${ }^{25}$ Jan Paweł II, Przesłanie do uczestników II Zgromadzenia Plenarnego Papieskiej Komisji ds. Kościelnych Dóbr Kultury, w: Jan Paweł II. Dzieła zebrane, t. 5, Kraków 2007, s. 312. 


\section{Selected painting poses of John Paul II}

The papal painting of Joanna Sobczyk-Pajak is a part of her life. Through her painting, she communicates certain information to the viewers and tries to interact with them. Communication, being a part of everyday life, articulates emotions, suffering, reverie, joy or fear. The artist herself will add that the creator of the image, by obtaining a specific form, makes " $a$ work of art a carrier of ideas. The convention applied and the artist's personality give the work its character of a language. Therefore, it is able to express hidden contents, becoming an important link in the process of communication, evoking recipient's resonance" ${ }^{26}$. Her papal painting does not provoke, does not teach anyone, but encourages to think and pay attention, and above all, it proposes. From the whole painting spectrum of the Cracow artist, the following paintings will be presented: a blessing from a Vatican window, with hands spread across Poland and a hand covering the face.

\section{Blessing from the Vatican Window}

To bless someone is to wish him everything good for every day. John Paul II is shown in the open Vatican window. The painting depicts a saint facing away from the recipient, who stands and blesses. It is impossible not to stop at the vernissage by passing by. The colours are warm and friendly. You can see freedom and dynamics in the combination of colors and shapes. Different shades of green merge, which is considered to be a neutral colour, a middle way between charming blue and suggestive red. However, the same green symbolizes the vegetation that is awakening to life. For this reason, it is associated with hope, and hope is a component of the blessing.

Looking at the picture, you can also see a rose piercing through various shades of grey. This colour is associated with passion and empathy, and even with love, which may mean that there is no love without empathy, nor empathy without love, but love and empathy are also the components of the blessing. After all, the white of the papal cassock, symbolizing innocence, also speaks of a new beginning and is the opening of a new card of life.This means that the whiteness is also expressed in the blessing. It also means that the Blessing Pope encourages a new quality of life. The artist seems to be clearly encouraging this new quality of life.

${ }^{26}$ J. Sobczyk-Pająk, Wizerunek współczesnego świętego w malarstwie formą komunikacji ze światem, w: Św. Joanna Beretta Molla. Komunikacja i społeczne oddziaływanie, red. R. Nęcek, J. Sobczyk-Pająk, Kraków 2019, s. 95. 
With hands spread across Poland

The painting depicts John Paul II covering the whole of Poland with his hands. The hands spread are open to the issues and problems of the nation and concern with them. It is a closeness full of empathy and understanding. In the distance you can see gray colours and piling clouds of gray smoke, although in a stronger shade. Greyness is a symbol of a certain insecurity, and being neutral is conducive to solving disputes. The white figure of the Pope and his hands spread out are also a symbol of intercession with God and a request to Him that His providence should cover the whole country. Certainly, this image speaks to people of all epochs, because there are always problems of the country, although they are different depending on the time and historical context. Of course, looking at the paintings of the Cracow artist, it should be noted that what painting "communicates to the viewer is also dependent on him/her"27.

With a hand that covers the face

The artist depicts a pope praying. His face, covered by his hand, is sunk in prayer. Here is a holy man focused on a conversation with the absolute, with God. It is interesting to see Joanna Sobczyk-Pajak, who emphasizes that "one cannot let oneself be carried away by one's own painting vision if one wants the painting to reflect the saint's person and communicate the contents that he or she passed on during his or her lifetime"28. The colours of this work are shrouded in grey, intertwined with the white of the Holy Pope. The contours of the hand clearly outlined show the ring of the fisherman in the shape of a small cross. The golden or gold ring expresses love for God, that is, love is a ring, and the ring has no end. At the same time it is a sign of attachment, trust and covenant. One could boldly emphasize the great Pope's intercession prayer and his union with God. In this way, beauty is revealed, which "undoubtedly becomes the goal of the act of communication, and beauty is what makes man better and more noble"29.

${ }^{27}$ Tamże, s. 96.

${ }^{28}$ J. Sobczyk-Pająk, Wizerunek współczesnego świętego $w$ malarstwie formą komunikacji ze światem, w: Św. Joanna Beretta Molla. Komunikacja i społeczne oddziaływanie, red. R. Nęcek, J. Sobczyk-Pająk, Kraków 2019, s. 98.

${ }^{29}$ J. Sobczyk-Pająk, R. Nęcek, Komunikacja piękna. Papieskie wernisaże w Makao i w Krakowie, Krakow 2019, s. 5-6. 


\section{THE MANIFESTATIONS OF PAPAL COMMUNICATION IN THE PAINTING MESSAGE OF JOANNA SOBCZYK-PAJĄK}

Image is a universal mean of communication, and "The Church needs art. It must make the spiritual, invisible, divine reality visible and even attractive as far as possible. Therefore, it must express in understandable formulas what in itself is inexpressible"30. This means that the words on which communication is based are simply not enough. Therefore, the image acquires an analogous function to the presented message ${ }^{31}$. One can even say that Joanna Sobczyk-Pajak educates with an image that becomes an essential element of a deeper perception of the world and communication with it. In this perspective, in the painting of the artist one can notice the manifestations of papal communication with God, human being and the nature. In support of these words, the following will be presented: prayer at the Wailing Wall of Jerusalem, contemplative amazement on the mountains, a smile as the beginning of communication and listening reflected in the eyes.

\section{Prayer at the Wailing Wall in Jerusalem}

The picture of the pope standing in front of the Jerusalem Wailing Wall is impressive. The Holy Pope communicates with God in a quiet gesture of folding a prayer card in the gap of the Wall. Here is a man in white against the background of various shades of gray, submerged in divine dialogue. Slightly humped, his head bent down. Against the background of not clear colours, white is visible in full outlines. Different intensity of colours increases the clarity of the image and helps to distinguish the essential planes of life from each other. This means that the language of colours and shapes supports the intuition of the viewer, they try to introduce it into the world of the spirit of the immaterial, so that it does not get lost in the material. Communication between what is visible and what is invisible.

This image has an exceptional impact on the senses, and its communicativeness brings the viewer closer to the spiritual world. In this case, the image becomes a message of beauty, what brings us closer and what we long for. It is worth

${ }^{30}$ Jan Paweł II, List do artystów, Watykan 1999, nr 12.

${ }^{31}$ Por. M. Strączyńska, Synergia obrazu i tekstu w projektowaniu komunikacji wizualnej. Poszukiwanie i analiza najważniejszych przykładów skutecznego łączenia obrazu i tekstu w kontekście edukacyjnym, Maszynopis - doktorat, Uniwersytet Śląski, Wydział Artystyczny, pod kierunkiem dr. hab. Łukasza Klisia, Cieszyn 2017, s. 5. 
noting in this context that "contemporary man should be able to read everywhere from archaeological excavations to the most modern forms of Christian art - the history of the Church, so that thanks to this it would be easier for him to see the mysterious beauty of God's saving plan"32.

\section{Contemplative amazement on the mountains}

As an artist, Joanna Sobczyk-Pajak is well aware that contemplation of mountains leads to contemplation of God. The author of the painting clearly appreciates what is usually underestimated in life - communication with God and adoration of beauty. When beauty is perceived as beauty, a sense of adoration occurs spontaneously. Then one would like to embrace the whole fullness with one's eyes, looking at it and admiring it in silence, because beauty is there to delight, and the fullness of this beauty to encourage adoration. The white silhouette of Pope Wojtyla, leaning against a wooden stick and reflecting on the water surface, directly calls to the recipient: come closer and contemplate the face of the Almighty. On the one hand, the beauty of the mountains intimidates, and on the other hand, it encourages to admire. When beauty is discovered in its entirety, joy and a feeling of respect and even greater feeling of gratitude appear. Then a bond is born open to infinity and common cooperation. When painting this picture, the author was aware of the fact that contemplation is a real desire to come near what is beautiful.

\section{Smile as an introduction to communication}

This image is clearly suggestive. Here is the Pope smiling at the people he meets and showing his coming from the meeting. A smile is an invitation to dialogue and communication. Of course, a smile coming from the heart is a decoration of a man's ordered interior. That is why Joanna Sobczyk-Pajak had to get to know the Pope's biography well in order to be able to show so realistically the papal expression of joy. The artist herself emphasizes that "it is impossible to paint a figure well without knowing its life story and the message it brings"33.

${ }^{32}$ Jan Paweł II, Przesłanie do uczestników II Zgromadzenia Plenarnego Papieskiej Komisji ds. Kościelnych Dóbr Kultury, w: Jan Paweł II. Dzieła zebrane, t. 5, Kraków 2007, s. 312.

${ }^{33} \mathrm{~J}$. Sobczyk-Pająk, Wizerunek współczesnego świętego $w$ malarstwie formą komunikacji ze światem, w: Św. Joanna Beretta Molla. Komunikacja i społeczne oddziaływanie, red. R. Nęcek, J. Sobczyk-Pająk, Kraków 2019, s. 98. 
The face of John Paul II clearly radiating with sunlight, eyes slightly squinted and expressing warmth beating from the inside. A slightly tousled hair and the hand of a met man placed on his shoulder clearly suggest a fascinating atmosphere of the meeting and minimized distance. A smile that captivates a good person and leaves the other person's heart refreshed, calm and rich of willingness to live. This image appeals to the imagination and strikes with the simplicity of the message telling the audience that a smile can be a prelude to communication.

\section{Listening reflected in the eyes}

Undoubtedly, eyes are the most important deceit of man, thanks to which you can find yourself in the surrounding world. The artist has shown them in an exceptional way in all their sharpness. One could risk a statement that only eyes are clear, everything else is shrouded in light mist of various grayscale varieties. The eyebrows are wrinkled and the eyes are gazed, as if the pope was trying to listen carefully. Who? When taking into account folded hands, it seems to be God. Anyway, when a man can be focused on God, he can also focus on another man.

In this way the recipient can receive a simple message - focusing on the other and the ability to listen to it is an essential condition for successful communication and mutual understanding. There must be no hurry in listening, there must be a stop in listening. It should be emphasized that listening to the Pope's eyes is a sign of longing for concentration, for listening, for opening up to one's neighbor. It is a longing for a human and heartfelt conversation. It is not by chance that people who are enchanted by people look into each other's eyes and read what others are unable to read.

\section{CONCLUSION}

To sum up, it should be stated that the papal painting of Joanna Sobczyk-Pajak is a communication of beauty. John Paul II in a painting, fascinates at every step and in the way in which he amazed the world during his lifetime. Of course, art is such a dimension of human life that it can pose questions or answer them. Everything depends on the imagination of the artist and the recipient himself. It seems, however, that the painting by the Cracow artist from Podłęże is a call for basic values that make human life beautiful and meaningful. There is no pressure in this painting. Talking to the audience through the painting and serving them manifestations 
of papal communication, he asks people living today about the values in their lives, about the sense of beauty, about the liberation of harmony in the heart.

\section{John Paul II in a painting, fascinates at every step and in the way in which he amazed the world during his lifetime.}

So it is not accidentally that John Paul II, addressing the Pontifical Commission for Church Cultural Assets, stated that "one should also take care of new creativity, establishing personal contact with creators, showing them greater attention and readiness to help, so that also in our era, works are created that will be a testimony of faith and the presence of the Church in the history of the world"34.

\section{REFERENCES}

Benedykt XVI, Sztuka i kultura umacniaja naszq więź z Panem (Castel Gandolfo, 30.08. 2011), „L'Osservatore Romano” nr 10-11 (2011), s. 45.

Benedykt XVI, Nowe technologie, nowe relacje. Trzeba rozpowszechniać kulturę szacunku, dialogu i przyjaźni. Orędzie na 43 Światowy Dzień Środków Społecznego Przekazu, „L'Osservatore Romano” nr 3 (2009), s. 5.

Franciszek, Wiarygodni i konsekwentni. Spotkanie z seminarzystami, nowicjuszami i nowicjuszkami (6.07.2013), „L’Osservatore Romano” nr 8-9 (2013), s. 42-43.

Franciszek, Prawdziwa władza jest służba, Kraków 2013.

Goban-Klas T., Komunikowanie i media, w: Dziennikarstwo i świat mediów, red. Z. Bauer, E. Chudziński, wy. II zm., Kraków 2000, s. 11-31.

Golka M., Bariery w komunikowaniu i społeczeństwo (dez) informacyjne, Warszawa 2008.

Jan Paweł II, Orędzie na XVI Światowy Dzień Środków Społecznego Przekazu - 1982. Środki społecznego przekazu a problemy ludzi starszych, w: Jan Paweł II, Dzieła zebrane, t. IV, Kraków 2007, s. 875-878.

Jan Paweł II, Orędzie na XVIII Światowy Dzień Środków Społecznego Przekazu - 1984. Środki społecznego przekazu pomostem między wiara i kultura, w: Jan Paweł II, Dzieła zebrane, t. IV, Kraków 2007, s. 882-885.

Jan Paweł II, Orędzie na XXXIV Światowy Dzień Środków Społecznego Przekazu - 2000, w: Jan Paweł II, Dzieła zebrane, t. IV, Kraków 2007, s. 932-934.

${ }^{34}$ Jan Paweł II, Przesłanie do uczestników II Zgromadzenia Plenarnego Papieskiej Komisji ds. Kościelnych Dóbr Kultury, w: Jan Paweł II. Dzieła zebrane, t. 5, Kraków 2007, s. 312. 
Jan Paweł II, Orędzie na XXXVI Światowy Dzień Środków Społecznego Przekazu - 2002, w: Jan Paweł II, Dzieła zebrane, t. IV, Kraków 2007, s. 937-939.

Jan Paweł II, List do artystów, Watykan 1999.

Jan Paweł II, Przesłanie do uczestników II Zgromadzenia Plenarnego Papieskiej Komisji ds. Kościelnych Dóbr Kultury, w: Jan Paweł II. Dzieła zebrane, t. V, Kraków 2007, s. 311-313.

Nęcek R., Od kapłaństwa do społeczeństwa. Wybrane kwestie z nauki społecznej papieża Franciszka, Kraków 2014.

Norwid C.K., Promethidion: Bogumit, w: Pisma wybrane, t. II, Poematy, Warszawa 1968.

Słownik Wyrazów Obcych PWN, Wydanie nowe I, Warszawa 1995.

Sobczyk-Pająk J., Wizerunek współczesnego świętego w malarstwie formq komunikacji ze światem, w: Św. Joanna Beretta Molla. Komunikacja i społeczne oddziaływanie, red. R. Nęcek, J. Sobczyk-Pająk, Kraków 2019, s. 89-99.

Sobczyk-Pająk J., Nęcek R., Komunikacja piękna. Papieskie wernisaże w Makao i w Krakowie, Kraków 2019.

Strączyńska M., Synergia obrazu i tekstu w projektowaniu komunikacji wizualnej. Poszukiwanie i analiza najważniejszych przykładów skutecznego łączenia obrazu i tekstu w kontekście edukacyjnym, Maszynopis - doktorat, Uniwersytet Śląski, Wydział Artystyczny, pod kierunkiem dr. hab. Łukasza Klisia, Cieszyn 2017.

Szpecht-Abramiuk Z.S., Piękno $w$ doświadczeniu egzystencjalnym Karola Wojtyły - Jana Pawła II, „Warszawskie Studia Teologiczne” nr 1 (2011), s. 29.

Życiński J., Wartości w eterze, Lublin 1999.

\section{Biogram}

Robert Nęcek - ksiądz archidiecezji krakowskiej, doktor habilitowany nauk społecznych, kierownik Katedry Edukacji Medialnej w Instytucie Dziennikarstwa i Komunikacji Społecznej na Wydziale Nauk Społecznych Uniwersytetu Papieskiego Jana Pawła II. Konsultor Rady ds. Środków Społecznego Przekazu Konferencji Episkopatu Polski. W latach 2005-2016 rzecznik prasowy Archidiecezji Krakowskiej. Na wniosek Komisji ds. Nagród Rektorskich UPJPII rektor przyznał mu nagrodę za wybitne osiągnięcia dydaktyczne i organizacyjne $(2010,2017)$. Autor wielu artykułów naukowych w Polsce, Niemczech, Austrii, na Słowacji, w Indiach, Hiszpanii i kilku książek naukowych w Polsce i we Włoszech. Wyróżniony medalem Mater Verbi. W 2016 roku odznaczony złotą odznaką św. Floriana Mazovia II klasy za wyjątkową skuteczność i kompetencje medialne. Laureat nagrody Feniksa Specjalnego 2017.

e-mail: robert.necek@upjp2.edu.pl,https://orcid.org/0000-0001-8576-9908 